\title{
Role of expectations in land allocation towards fruit crops: the case of apple
}

\author{
Pradeep Kumar MEHTA
}

Flat No.6, GH-8, Sector 5 , MDC, Panchkula, 134109 Haryana, India pradeep_mehta@yahoo.com

${ }^{*}$ Correspondence and reprints

Received 21 September 2009 Accepted 7 December 2009

Fruits, 2010, vol. 65, p. 315-323 (C) 2010 Cirad/EDP Sciences All rights reserved DOI: $10.1051 /$ fruits/2010027 www.fruits-journal.org

RESUMEN ESPAÑOL, p. 323
Role of expectations in land allocation towards fruit crops: the case of apple.

Abstract - Introduction. Higher allocation of land in favour of fruits is vital to raise the farm income and productivity, but such an opportunity is also complemented with higher risk and uncertainty. Economic expectation assumes a great role, while such decisions have an impact on the welfare of farmers in terms of their income and risk. In this paper, we examined the nature of price expectations, their relationship with other economic factors, and analysed the importance of price and income expectations of the fruit (apple) growers on their land allocation decisions. Materials and methods. In this paper, the elicitation technique was used to obtain both price and income expectations of apple growers. The price expectations were compared with the actual price of apple over the last three years and then linked with farmers' input-use propensities. A regression method was used to identify the role of expectations in the decision of land allocation in favour of apple crops. Results and conclusion. Our results showed that better price expectation improves the input-use (generally labour) propensities. However, for allocation of the inelastic factor of production, i.e., land, in favour of a fruit crop, it is the income expectations that explain farmers' decisions. Farmers' capacity to generate higher productivity along with the better market prospects together explain their decision regarding allocating land to high value fruit crops.

India / Malus / fruit growing / socioeconomic environment / land use / farm income

\section{Rôle de l'anticipation dans l'allocation des terres en cultures fruitières : le cas du pommier.}

Résumé - Introduction. De meilleures attributions de terres en faveur des arbres fruitiers seraient essentielles pour améliorer les revenus agricoles et la productivité, mais une telle orientation est également assortie d'un certain risque et d'incertitude. Les anticipations économiques jouent un rôle important, puisque de telles décisions ont un impact sur le bien-être des agriculteurs en termes de revenus et de risques. Dans cet article, nous avons examiné la nature des anticipations du prix et des revenus par les producteurs de fruits (pommes) vis-àvis de leurs décisions d'affectation des terres. Matériel et méthodes. Dans cet article, la technique de collecte d'informations a été utilisée pour obtenir des anticipations de prix et de revenus par les producteurs de pommes. Les anticipations de prix ont été comparées avec le prix réel des pommes au cours des trois dernières années et liées à la propension des agriculteurs à utiliser des intrants. La méthode de régression a été utilisée pour identifier le rôle de l'anticipation dans la décision d'allocation des terres en faveur de la culture du pommier. Résultats et conclusion. Les résultats ont montré que l'attente de meilleurs prix améliore la propension à utiliser des intrants (main-d'œuvre, en général). Toutefois, pour l'allocation du facteur inélastique de production, à savoir, la terre, en faveur d'une culture fruitière, ce sont les attentes de revenus qui expliquent la décision des agriculteurs. La capacité des agriculteurs à générer une productivité plus élevée avec de meilleures perspectives commerciales explique leur décision concernant l'attribution des terres à des cultures fruitières à valeur élevée.

Inde / Malus / culture fruitière / environnement socioéconomique / utilisation des terres / revenu de l'exploitation 


\section{Introduction}

Apple (Malus Pumila Mill.) is one of the high value commercial crops that are grown in huge quantity in the northern states of India, including Himachal Pradesh, Jammu and Kashmir and Uttaranchal. Apple is the fourth major fruit crop of the country with an approximate annual production of $1.42 \mathrm{Mt}$ [1]. With respect to area under cultivation for fruits, apple has the third largest area under cultivation in India after banana and mango [2].

Increasing the share of apple in the area under cultivation is desirable due to its significance in raising land productivity and farm income. However, the decision of land allocation among different crops is taken in an environment where the outcomes of such decisions are not perfectly known. Consequently, the land allocation decisions by farmers involve consideration of risk and uncertainty in the production process [3]. The economic variables which link successive time periods are expectations and attitudes of farmers, their entrepreneurial decisions and acts (mainly land allocation between low value subsistence crops and high value commercial crops) resultant of those decisions [4]. Though the motivation for increasing the area under apple is the potential of generating high income, productivity and employment, this is also considered as a risky crop. The major feature of apple is that its price fluctuates widely even within a single season. Lack of a support price and high perishability of the crop make the apple growers even more vulnerable to risk and uncertainty than growers of other high value crops such as rice or sugarcane. In the event of a greater extent of risk and uncertainty, expectations assume a greater role in the resource allocation decisions. Farmers build expectations based on changes in the price and production potential of the crop and accordingly invest or allocate resources among crops and activities [5, 6].

At the micro-(farm) level, the concept of expectation is generally used in terms of a response to uncertainty involved in the production process. There are several ways in which the information regarding the expec- tation is obtained at the farm level. Such information pertains to the probability and possibility of different prices, incomes or events. The specific questions include: which price level farmers consider as most profitable, what is the possibility of different ranges of prices, what is the probability of occurrences of different levels of prices, and which level of prices surprises farmers, etc. [4, 6-9]. Most of the available literature on the topic seems to lay more emphasis on the price expectations only but, in general, farmers tend to have expectations about different economic outcomes including change in price and yield. Price may not be the only factor in decision-making; heterogeneity in resources and capital endowments of the farmers and access to input and output markets, all together affect the output and its variability. Difference in the level of crop yields influences revenue directly and hence both price and output are important. It could be hypothesised that farmers with a relatively higher level of crop productivity may allocate more land to high value crops even at a low expected price. In this context, it is vital to examine the link between the price and income expectation in the land allocation decisions by the farmers.

In this paper, using the elicitation technique, both the price and income expectations of apple growers were obtained. The price expectations are also compared with the actual price of apple experienced by farmers in the last three years. We then linked the price expectations by the apple growers with their input-use propensities and land allocation decisions. Finally, we analysed the role of different expectations (price and income) in the land allocation decisions of apple growers.

\section{Sampling and methodology}

This study was carried out in the Theog block of Shimla district in Himachal Pradesh, the horticultural state of India, where fruits contribute significantly to the total value of output in the agricultural sector. Sub-regions (villages, namely: Sandhu and Shilaru) were selected from this region on the basis of a higher amount of area 
Table I.

Farm size and sampling from two selected villages in India, Sandhu and Shilaru, to survey the role of expectations in land allocation for apple crops.

\begin{tabular}{|c|c|c|c|c|c|c|c|c|c|c|}
\hline \multirow[t]{2}{*}{ Villages } & \multicolumn{2}{|c|}{$\begin{array}{l}\text { Marginal farmers } \\
\quad(<1 \mathrm{ha})\end{array}$} & \multicolumn{2}{|c|}{$\begin{array}{l}\text { Small farmers } \\
\quad(1-2 \text { ha })\end{array}$} & \multicolumn{2}{|c|}{$\begin{array}{l}\text { Semi-medium farmers } \\
\text { (2-4 ha) }\end{array}$} & \multicolumn{2}{|c|}{$\begin{array}{l}\text { Medium farmers } \\
\qquad(4-10 \mathrm{ha})\end{array}$} & \multicolumn{2}{|c|}{$\begin{array}{l}\text { Large farmers } \\
\quad(>10 \mathrm{ha})\end{array}$} \\
\hline & $\begin{array}{l}\text { Number } \\
\text { of farmers }\end{array}$ & $\begin{array}{l}\text { Sample } \\
\text { collected }\end{array}$ & $\begin{array}{l}\text { Number } \\
\text { of farmers }\end{array}$ & $\begin{array}{l}\text { Sample } \\
\text { collected }\end{array}$ & $\begin{array}{l}\text { Number } \\
\text { of farmers }\end{array}$ & $\begin{array}{l}\text { Sample } \\
\text { collected }\end{array}$ & $\begin{array}{l}\text { Number } \\
\text { of farmers }\end{array}$ & $\begin{array}{l}\text { Sample } \\
\text { collected }\end{array}$ & $\begin{array}{l}\text { Number } \\
\text { of farmers }\end{array}$ & $\begin{array}{l}\text { Sample } \\
\text { collected }\end{array}$ \\
\hline Sandhu & 17 & 3 & 47 & 9 & 63 & 14 & 15 & 3 & 6 & 1 \\
\hline Shilaru & 11 & 2 & 29 & 6 & 51 & 12 & 30 & 7 & 14 & 3 \\
\hline
\end{tabular}

Source: primary data.

Table II.

Demographic features of 60 farmers selected from two villages in India, Sandhu and Shilaru, surveyed for the role of expectations in land allocation for apple crops.

\begin{tabular}{lccccccc} 
Villages & $\begin{array}{c}\text { Average age } \\
\text { of the household } \\
\text { head } \\
\text { (years) }\end{array}$ & $\begin{array}{c}\text { Number } \\
\text { of households } \\
\text { headed } \\
\text { by illiterate }\end{array}$ & $\begin{array}{c}\text { Average years } \\
\text { of experience } \\
\text { in farming }\end{array}$ & $\begin{array}{c}\text { Number } \\
\text { of households } \\
\text { headed } \\
\text { by females }\end{array}$ & $\begin{array}{c}\text { Average number } \\
\text { of household } \\
\text { members }\end{array}$ & $\begin{array}{c}\text { Average number } \\
\text { of household members } \\
\text { not involved }\end{array}$ & $\begin{array}{c}\text { Resourceconstraint: } \\
\text { [Land / labour] }\end{array}$ \\
Sandhu & 61.13 & 9 & 20.40 & 7 & 6.2 & 1.6 & 4.35 \\
Shilaru & 61.50 & 13 & 23.46 & 7 & 6.3 & 1.9 & 7.56 \\
Total & 61.31 & 22 & 21.93 & 14 & 6.25 & 1.75 & 5.95 \\
\hline Source: primary data. & & & & & & &
\end{tabular}

under fruit crops (apple). Apple is the major crop in these villages, that covers $85 \%$ and $89 \%$, respectively, of total cultivated area. In total, sixty farmers were interviewed, with 30 farmers from each village, following a stratified and proportional random sample approach (table I). Most of the farmers belong to the category of semi-medium and medium farm size (own land between $2 \mathrm{ha}$ and $10 \mathrm{ha}$ ). The selected farm households were, in general, headed by old persons as the average age of the household head is 61.31 years (table II). The incidence of illiteracy among the household heads was quite high and farmers, in general, had more than twenty years of experience in apple farming. The households were mostly headed by male members with an average family size of six members per household. Interestingly, apple growers were experiencing shortage of labour, as indicated by a higher land-labour ratio (5.95), which could act as a constraint in a higher level of land allocation towards the apple, which is a labour-intensive crop.
To address the objectives of this paper, the elicitation technique was used to obtain both price and income expectations of apple growers. Farmers tend to build expectations about the outcome of price, yield, profitability and risk patterns, which are based on their past experiences of different ranges of price, and yield of crops. Therefore, before obtaining the information on expectations from farmers, we obtained their experience of the minimum and maximum prices and production of apple ${ }^{1}$. Then, the question was asked about the most expected price and production of the crop that have influenced them to take the land allocation decision. The price expectations were compared with the actual prices experienced by farmers in the last three years and then linked

1 'Good and bad years' in the production and price is a general feature of the agricultural sector, especially in developing countries, and this also influences the revenue from the crop. 
Table III.

Farmers' experience with price of apple (INR: Indian rupee). In total, 60 farmers were selected from two villages in India, Sandhu and Shilaru, and were surveyed regarding land allocation for apple crops. Means are 17.41 INR $\cdot \mathrm{kg}^{-1}$ for expected price, $10.20 \mathrm{INR} \cdot \mathrm{kg}^{-1}$ for minimum price, $25.60 \mathrm{INR} \cdot \mathrm{kg}^{-1}$ for maximum price.

\begin{tabular}{|c|c|c|c|c|c|}
\hline $\begin{array}{l}\text { Expected price } \\
\quad\left(\text { INR } \mathrm{kg}^{-1}\right)\end{array}$ & Number of farmers & $\begin{array}{l}\text { Minimum price } \\
\left(\text { INR } \cdot \mathrm{kg}^{-1}\right)\end{array}$ & Number of farmers & $\begin{array}{l}\text { Maximum price } \\
\left(\text { INR } \cdot \mathrm{kg}^{-1}\right)\end{array}$ & Number of farmers \\
\hline 8 & 1 & 2 & 1 & 20 & 5 \\
\hline 11 & 1 & 4 & 1 & 21 & 1 \\
\hline 12 & 1 & 5 & 2 & 22 & 9 \\
\hline 13 & 1 & 6 & 9 & 24 & 18 \\
\hline 14 & 3 & 7 & 1 & 26 & 6 \\
\hline 15 & 6 & 8 & 7 & 28 & 9 \\
\hline 16 & 15 & 9 & 1 & 30 & 5 \\
\hline 17 & 3 & 10 & 16 & 32 & 5 \\
\hline 18 & 8 & 12 & 8 & 36 & 2 \\
\hline 19 & 4 & 14 & 5 & - & - \\
\hline 20 & 12 & 15 & 2 & - & - \\
\hline 22 & 1 & 16 & 6 & - & - \\
\hline 23 & 1 & 18 & 1 & - & - \\
\hline 24 & 2 & - & - & - & - \\
\hline 25 & 1 & - & - & - & - \\
\hline
\end{tabular}

with farmers' input-use propensities. A regression (log-linear) method was used to identify the role of expectations in the decision of land allocation in favour of apple crops.

\section{Price expectations at farm level}

In this section, we will first present the price expectations of farmers, and then farmers' expected outcomes about prices will be compared with actual prices received by the farmers. Then, the factors influencing price expectations of apple growers will be identified.

\subsection{Dynamics of price expectations of apple growers}

It is vital to understand the dynamics of price expectations of farmers as they take their decisions in an uncertain environment [5]. The data on price expectations of apple growers illustrated that the average value of the expected, minimum and maximum prices was INR (Indian Rupee) 17.41, INR
10.20 and INR 25.60 per $\mathrm{kg}$, respectively (table III). Almost equal numbers of farmers received prices below as well as above the average value of the expected price of apple, i.e., INR 17.41. In addition, 63\% of the farmers received a price that was far below the average value of the minimum price of the crop (INR 10.20), which means that majority of the apple growing farmers experienced low or unfavourable prices. More importantly, only $20 \%$ of the farmers were able to get more than INR 30 per $\mathrm{kg}$ for apple. The experience of farmers with price reflected that huge differences exist in terms of price received by the farmers in marketing of apple.

The results of price expectations of apple were compared with the actual harvest prices. The procedure used was similar to that of Grisley and Kellogg; the deviation between the two sets were computed by using the data on actual prices as experienced by farmers in the last three years and expected prices by the farmers. The distribution of farmers falling within different ranges of deviation between expected values and actual values was registered (table IV). The farmers falling under the category of negative deviation are the ones 
Table IV.

Number of farmers (total of 60 farmers) who were registered for price deviation between actual and expected values of apple price.

Deviation between actual and expected prices Number of farmers

$<-20 \%$

$-20 \%$ to $-10 \%$

$-10 \%$ to $0 \%$

0 to $10 \%$

$10 \%$ to $20 \%$

$>20 \%$

Source: primary data.

who had reported their expectations as less than the actual harvest outcomes ${ }^{2}$. Interestingly, more than $80 \%$ of the apple growers received a price above their expected price. There are only 11 farmers whose expected prices are greater than the average price of the last three years. This shows that there is a greater time-lag (and not just a three-year period) in which a farmer's expectations are shaped.

\subsection{Price expectation relation with other economic factors}

According to economic theory, price expectation is likely to exert a strong influence on the behaviour of farmers regarding resource allocation, including inputs such as land, labour and capital. Generally, farmers who expect a better price are likely to engage in more resource intensiveness as compared with others. We analysed the influence of price expectation on the input-use propensities of the farmers, which affects the economic outcomes in terms of productivity and income. Then, we identified the factors that influenced the price expectations by the apple growers.

The input propensities of apple growers show that the farmers with higher price expectations exhibit higher labour intensity

\footnotetext{
${ }^{2}$ For instance, if the price expected by farmers is 10 Indian Rupees and the actual price in the market (mean price of the crop for the years 2004, 2005 and 2006) is 12 Indian Rupees , farmers would fall under the group of deviation of [- $20 \%$ to $-10 \%]$ as deviation turned out to be $-16.66 \%$.
}

as they hire more labour to carry out production and marketing activities; the group of farmers with higher price expectations from apple employ 235 man-days per ha as compared with 192 man-days per ha by the farmers with a low expected price from apple (table $V$ ). Interestingly, better price expectations also positively influence the willingness to pay for labourers for their work, and the willingness of farmers to reinvest their profit in the crop-related activities. This illustrates that price expectations are vital for the input-use propensities of farmers. In other words, better expectations about the price influence the propensity to involve more and better use of inputs.

Both economic and non-economic factors are considered in identifying variables that influence price expectations of apple growers (table VI). From the results, it is clear that price expectation by farmers is greatly influenced by their past experience with the range of prices. Farmers with higher price expectations have experienced a higher price (INR 28.47) per kg as compared with farmers of other groups. At the same time, farmers with higher price expectation did not experience a very low price for the crop, which was INR 10.65 per $\mathrm{kg}$ in comparison with INR 8.75 per $\mathrm{kg}$ for farmers with low price expectation. Interestingly, the farmers with higher price expectation also have higher yield expectation, which stands at $43.20 \mathrm{~kg}$ per plant against $37.27 \mathrm{~kg}$ per plant for the farmers with low price expectations. In terms of socio-economic characteristics, farmers with high price expectations are younger and more educated. Their household is mainly headed by 
Table V.

Input-use propensities of 60 selected apple growers (selected from two villages, Sandhu and Shilaru in India), according to different price expectations.

\begin{tabular}{|c|c|c|c|c|c|c|c|c|}
\hline $\begin{array}{l}\text { Price } \\
\text { expectation } \\
\text { of apple } \\
\text { growers }\end{array}$ & $\begin{array}{l}\text { Number } \\
\text { of farmers }\end{array}$ & $\begin{array}{c}\text { Price } \\
\text { expectations } \\
\text { (Indian rupees) }\end{array}$ & $\begin{array}{c}\text { Irrigation } \\
\text { intensity [net } \\
\text { irrigated area } \\
\text { / net cropped } \\
\text { area] }\end{array}$ & $\begin{array}{l}\text { Labour } \\
\text { intensity } \\
\text { (man-days per } \\
\text { ha) }\end{array}$ & $\begin{array}{l}\text { \% of } \\
\text { households } \\
\text { hiring labour } \\
\text { for farm } \\
\text { purposes }\end{array}$ & $\begin{array}{l}\% \text { of farmers } \\
\text { willing to pay } \\
\text { high amount } \\
\text { for labour hiring }\end{array}$ & $\begin{array}{c}\% \text { of farmers } \\
\text { willing to reinvest } \\
\text { profit }\end{array}$ & $\begin{array}{c}\text { Share of area } \\
\text { under the selected } \\
\text { crop to gross cropped } \\
\text { area }\end{array}$ \\
\hline Low & 28 & $<16$ & 13.05 & 192.41 & 49.21 & 64.28 & 53.55 & 71.24 \\
\hline Medium & 15 & 17 to 19 & 12.46 & 197.37 & 40.67 & 60.00 & 66.66 & 71.87 \\
\hline High & 17 & $>19$ & 5.55 & 235.61 & 75.00 & 88.23 & 70.55 & 69.23 \\
\hline
\end{tabular}

Source: primary data.

Table VI.

Factors explaining price expectations of 60 apple growers from two selected villages surveyed in India (INR: Indian rupee). Average crop income is the mean of the maximum expected income and minimum expected income from apple, i.e., [(maximum expected income + minimum expected income) / 2].

\begin{tabular}{|c|c|c|c|c|c|c|c|c|c|c|c|}
\hline $\begin{array}{l}\text { Price } \\
\text { expectation } \\
\text { of apple } \\
\text { growers }\end{array}$ & $\begin{array}{l}\text { Number } \\
\text { of } \\
\text { farmers }\end{array}$ & $\begin{array}{l}\text { Price } \\
\text { expectations } \\
\text { (Indian } \\
\text { rupees) }\end{array}$ & $\begin{array}{l}\text { Minimum } \\
\text { price } \\
\left(\text { INR } \cdot \mathrm{kg}^{-1}\right)\end{array}$ & $\begin{array}{l}\text { Maximum } \\
\text { price } \\
\left(\text { INR } \cdot \mathrm{kg}^{-1}\right)\end{array}$ & $\begin{array}{l}\text { Expected } \\
\text { yield } \\
\text { (production } \\
\text { per plant) }\end{array}$ & $\begin{array}{l}\text { Average } \\
\text { crop } \\
\text { income } \\
\text { over paid } \\
\text { out cost } \\
\text { (INR) }\end{array}$ & $\begin{array}{l}\text { Distance } \\
\text { of farm } \\
\text { frommain } \\
\text { road } \\
\text { (m) }\end{array}$ & $\begin{array}{l}\text { Age of the } \\
\text { household } \\
\text { head } \\
\text { (years) }\end{array}$ & $\begin{array}{l}\text { Education of the } \\
\text { household head } \\
\text { (\% of households } \\
\text { headed by literate) }\end{array}$ & $\begin{array}{l}\text { Sex of the } \\
\text { household head } \\
\text { (\% of households } \\
\text { headed by male) }\end{array}$ & $\begin{array}{l}\text { Farm } \\
\text { size } \\
\text { (ha) }\end{array}$ \\
\hline Low & 28 & $<16$ & 8.75 & 24.46 & 37.27 & 122514 & 448.21 & 61.64 & 53.57 & 71.43 & 5.06 \\
\hline Medium & 15 & 17 to 19 & 12.41 & 24.81 & 34.36 & 115908 & 328.00 & 62.53 & 66.67 & 86.67 & 3.72 \\
\hline High & 17 & $>19$ & 10.65 & 28.47 & 43.20 & 252817 & 417.06 & 59.71 & 70.59 & 70.59 & 5.10 \\
\hline
\end{tabular}

Source: primary data.

male members and they have a larger farm size. A positive relation between farm size and price expectation reflects that a higher level of production helps in getting a good price on account of the better bargaining power in the market.

\section{Determinants of land allocation in favour of apple}

In order to capture the role of risk and uncertainty in the land allocation towards apple by farmers, variables which have a direct bearing on farmers' expectations about price and income ${ }^{3}$ were identified along with their focused revenue from the crop, variation in crop revenue, cost of pro-

${ }^{3}$ Gross income $\cdot h^{-1}$ of the crop. ducing the crop and farmers' disaster level of income ${ }^{4}$.

Expectations about the price of and income from the crop influence the prospective outcome that farmers expect from the extent of land allocation to a given crop. In general, farmers who expect high price and income from the crop are likely to have higher allocation of area in favour of a given crop. The role of focused income, which is the mean value of the focused gain and focused loss from the crop over a period of

${ }^{4}$ The disaster level of income is computed as $[d=\mathrm{MCN}-\mathrm{OFI}$, where MCN is the minimum consumption requirements of the farm family plus other critical expenditures by the household during a year and OFI is the annual off-farm income of the farm household. 


\begin{tabular}{|c|c|c|}
\hline Land allocation in favour of apple as a dependent variable & Coefficient & $t$-values \\
\hline Constant & 5.483 & 6.974 \\
\hline Expected price & -0.142 & -1.399 \\
\hline Expected income & $0.067^{\star}$ & 3.330 \\
\hline Focused income & $0.084^{*}$ & 3.989 \\
\hline Income variability & -0.038 & -1.608 \\
\hline Disaster level of income & $-0.120^{\star *}$ & -2.212 \\
\hline Cost of production & -0.051 & -1.312 \\
\hline
\end{tabular}

time $e^{5}$, is also examined in land allocation decisions. The higher the focused income from the crop, the more land is expected to be allocated in favour of a given crop. Higher variability in returns from the crop and higher cost of production are expected to adversely affect the land allocation decision. It is important to note that, while making the land allocation decision, the farmer takes different types of risks that include not only the risk of production but also that of consumption among others. The farmer enters into a trade-off situation while taking decisions on allocating area to commercial crops against food crops. Food consumption requirements at home along with the total food production capacity of the land tend to influence the extent of land allocation to the commercial crop. In other words, the greater the food requirement at home, the lesser the extent of land allocation to apple by the farmer could be. It is not only food crop requirements or expenditures that are of importance to farmers, but also other home expenditures such as children's education expenses, etc., which are even more important $[11,12]$. Therefore, here the disaster level of income is used as a variable, which includes all critical expenditures and

5 Most actions including land allocation decisions influence the outcomes which may be favourable or unfavourable. The extreme outcomes which are foreseen to be possible are termed as focus gain and focus loss by the farmers [10]. food requirements at home ${ }^{6}$. The disaster level of income is expected to effectively influence the allocation of land to high value apple crops. We have used a regression (loglinear) method to examine the role of these above-mentioned factors in land allocation decisions of apple growers: $\left[\left(a_{i} / \Sigma \mathrm{A}\right)=\right.$ f (EP, EY, FY, IV, DLY and COST)], where $\left(a_{i} / \Sigma \mathrm{A}\right)$ is the proportion of area under apple $\left(a_{i}\right)$ to the total net cropped area $(\Sigma \mathrm{A})$; EP is the expected price that farmers expect from apple (INR $\cdot \mathrm{kg}^{-1}$ ); EY is the expected income that farmers expect from apple $\left(\mathrm{INR} \cdot \mathrm{ha}^{-1}\right) ; \mathrm{FY}$ is the focused income, which is the mean value of the focused loss and gain by the apple grower (INR); IV is the income variability measured by the standard deviation of output of apple by using 3-year farm-level data (INR); DLY is the disaster level of income, which is the minimum income requirement at home (INR); COST is the cost of production of apple (INR $\cdot \mathrm{ha}^{-1}$ ).

${ }^{6}$ [11] provided [ $\left.d=\mathrm{MCN}+\mathrm{UD}-\mathrm{LA}-\mathrm{OFI}\right]$, where UD is the urgent debt and LA is the resale value of liquid assets. We have not included the data on LA as we found it extremely difficult to get such information from the interview and debt frequency by farmers for home needs in the selected villages is very low and negligible. However, we collected disaggregated information on the consumption needs and other critical expenditures at home and put it under MCN instead of taking the subjective levels of MCN by the farmers. 
This equation was converted into log-linear form and the new equation becomes: $\left[\ln \left(a_{i} / \Sigma \mathrm{A}\right)=\ln \mathrm{a}+b_{1} \ln \mathrm{EP}+b_{2} \ln \mathrm{EY}+b_{3}\right.$ $\ln \mathrm{FY}+b_{4} \ln \mathrm{IV}+b_{5} \ln \mathrm{DLY}+b_{6} \ln$ $\operatorname{COST}+\mu]$.

The coefficients were tested for statistical significance by using the ' $t$ ' test.

The results of the regression analysis indicate that income expectation and not the price expectation influences farmers' decisions of land allocation to apple; the income expectation variable is positive and statistically significant, whereas the expected price variable is negative and insignificant (table VII). The focused income from apple comes out positive and statistically significant. This shows that an expectation about the net gain from the production of the crop, over a period of time, greatly influences farmers to allocate land to apple. It is because apple has a gestation period of production and as land allocation in favour of apple is mostly inflexible in terms of reallocation of land to other crops. The disaster level of income has a negative influence on land allocation in favour of apple as the coefficient is negative and statistically significant. This shows that higher food consumption requirements and other critical expenditures do influence the behaviour of farmers in their decision in regard to allocating land to high value commercial crops (apple).

\section{Conclusions}

Higher allocation of land in favour of high value fruit crops is desirable from the point of view of raising farm income, land productivity and employment in the agricultural sector in India. In terms of economic factors, both price and income are the major incentives for the farmers to decide on the allocation of resources that include elastic and inelastic factors of production, such as land and labour. Additionally, the socio-economic factors including resource and capital endowment also influence the capacity to allocate land to high value crops as these crops require a high amount of labour and capital. In our paper, we examined the dynamics of price expectation, its relation with other economic and socio-economic variables and the role of different expectations in the land allocation in favour of a selected fruit crop, i.e., apple.

There exists great heterogeneity in terms of the level of price expected (price expectations) by apple growers. Such expected prices are generally lower than the actual price received by the farmers, when we compared the average price of apple (using the last three years' data) and expected price of apple. This shows that there is a greater time-lag (and not a three-year time period) in the prices experienced by the farmers in shaping price expectations from the crop. Interestingly, better price expectation improves the input-use (generally labour) propensities of the farmers. Also, price expectation is higher among the farmers with a larger farm size. Since, as it was found that higher expectation of price is also influenced by the level of the maximum price received by the farmer, it can be concluded that farmers with a larger farm size have a better advantage in terms of their bargaining power in the market. They could get higher prices for their produce as compared with small and marginal farmers.

Undoubtedly, higher price expectations improve the input-use propensity of apple growers in terms of greater intensity of labour, more willingness to pay hired labour and more willingness to reinvest profits in land and crop-related activities. However, for land allocation, it is the income expectations that are vital. In other words, for the land allocation decisions, price expectations alone may not explain the behaviour of the farmer, but it is the income expectations (combination of price and productivity) that is more important and explains farmers' decisions. Price expectations are important but they have a relatively lesser role in allocation of the inelastic factor of production, i.e., land towards high value crops. Farmers generally calculate the aggregate gain from the crop rather than referring only to the price of the crop. Their capacity to generate higher productivity along with the better market prospects together explain farmers' decisions regarding allocating land to high value crops. This explains that, though it is important to build a market structure in order to influence the better input-use propensities (generally labour) by the farmers, 
the same is insufficient for improving farmers' orientation to increase the inelastic factor of production, i.e., land in favour of high value crops such as apple.

\section{Acknowledgements}

The author is grateful to Prof. R.S. Deshpande for comments and suggestions on an earlier version of this article.

\section{References}

[1] Anon., National horticultural board database, Nat. Hortic. Board (NHB), New Delhi, India, 2008.

[2] Deodhar S.Y., What's keeping the apple away? Addressing the market integration issue, Indian Inst. Manag., Work. Pap., Ahmedabad, India, 2005.

[3] Heady E.O., Diversification in resource allocation and minimization of income variability, J. Farm Econ. 34 (1952) 482-496.

[4] Williams D.B, Price expectations and reactions to uncertainty by farmers in Illinois, $\mathrm{J}$. Farm Econ. 33 (1951) 20-39.
[5] Nowshirvani V.F., Land allocation under uncertainty in subsistence agriculture, Oxf. Econ. Pap. 23 (1971) 445-455.

[6] Shackle G.L.S., Expectation in economics, Camb. Univ. Press, Camb., U.K., 1949.

[7] Binswanger H.P., Attitudes toward risk: theoretical implications of an experiment in rural India, Econ. J. 91 (1981) 867-90.

[8] Grisley W., Kellogg E.D., Farmers' subjective probabilities in northern Thailand: An elicitation analysis, Am. J. Agric. Econ. 65 (1983) 74-82.

[9] Hardaker J.B., Some issues in dealing with risk in agriculture, Work. pap. Ser. Agric. Res. Econ. (2000) 1-18.

[10] Webster J.P.G., Kennedy J.O.S., Measuring farmers' trade-offs between expected income and focus-loss income, Am. J. Agric. Econ. 57 (1975) 97-105.

[11] Roumasset J.A., Rice and risk: decisionmaking among low-income farmers, N. Holl. Publ. Co., N.Y., U.S.A., 1976.

[12] Boussard J.M., Petit M., Representation of farmers' behaviour under uncertainty with a focus-loss constraint, J. Farm Econ. 49 (1967) 869-880.

\section{Papel del anticipo en la asignación de tierras en cultivos fructíferos: el caso del manzano.}

Resumen - Introducción. Para fomentar los ingresos agrícolas y la productividad, serían esenciales mejores atribuciones de tierras a favor de los árboles frutales. Sin embargo esto conlleva al mismo tiempo cierto riesgo de incertidumbre. Los anticipos económicos desempeñan un papel importante, ya que dichas decisiones tienen un impacto en el bienestar de los agricultores, en términos de ingresos y de riesgos. En este artículo, examinamos la naturaleza de los anticipos del precio, así como los ingresos por los productores de frutas (manzanas) en relación con sus decisiones de asignación de tierras. Material y métodos. En este artículo, se empleó la técnica de reunir información para que los productores de manzana obtuvieran anticipos de precio y de ingresos. Los anticipos de precio se compararon con el precio real de las manzanas en el curso de los tres últimos años; y, se relacionaron con la propensión de los agricultores en emplear insumos. El método de regresión se empleó para identificar el papel que tiene el anticipo en la decisión de asignación de tierras a favor del cultivo del manzano. Resultados y conclusión. Los resultados mostraron, que la esperanza de mejores precios arregla la propensión utilizar insumos (mano de obra, por norma general). No obstante, para la asignación del factor inseparable de la producción, es decir: la tierra, a favor de un cultivo fructífero, las esperanzas de ingresos son las que explican la decisión de los agricultores. La capacidad de los agricultores de gestionar una productividad más elevada, con mejores perspectivas comerciales, explica su decisión frente a la asignación de tierras para cultivos fructíferos de valor elevado.

India / Malus / fruticultura / entorno socioeconómico / utilización de la tierra / renta de la explotación 